\title{
A Gap Analysis on Urban Sustainability Studies and Urban Sustainability Assessment Tools
}

\author{
Cem Ayik ${ }^{1, *}$, Hatice Ayatac ${ }^{2}$, Begum Sertyesilisik ${ }^{3}$ \\ ${ }^{1} \mathrm{PhD}$ Program of Urban and Regional Planning, Graduate School of Science Engineering and Technology, Istanbul Technical University, \\ Istanbul, Turkey \\ ${ }^{2}$ Department of Urban and Regional Planning, Architecture Faculty, Istanbul Technical University, Istanbul, Turkey \\ ${ }^{3}$ Department of Architecture, Architecture Faculty, Istanbul Technical University, Istanbul, Turkey
}

\begin{abstract}
Urbanization rate has been accelerated especially due to industrialization. This acceleration has caused obstacles for healthy urbanization, (e.g. unplanned cities). Increase in the population and uncontrollable migration from rural areas to urban areas have contributed to this problem. New researches have been made and new terms have been created to solve this problem. Sustainability assessment became one of the popular terms in different research fields especially in the field of architecture and urban planning in recent years. This paper is based on an in-depth literature analysis and on the assessment tools analysis. 200 publications on urban sustainability published between 2000-2015 have been investigated with relevant key words. Besides this literature investigation, 6 world leading urban neighborhood sustainability assessment tools have been investigated. This study revealed two gaps in the literature and assessment tools with respect to the sustainable urban planning. These identified gaps are: the need for taking urban scale into account that has an important role for sustainability and the need for taking developing countries and their high population trends in the global sustainability assessment' This study is expected to contribute to the literature with respect to the lessons learned from the past and recent trends in the sustainable urban planning at the global scale.
\end{abstract}

Keywords Sustainable Urbanization, Gap Analysis, Literature Review, Assessment Tools, Urban Studies

\section{Introduction}

Urbanization and its impact on environment have started to increase rapidly after the Industrial Revolution. Afterwards new terms took place in the literature which highlighted importance of the nature as a result of unplanned population migration from rural areas to cities. The term "ecology" was used for the first time in a letter of Henry Thoreau in 1858.

Industrial settlements have not only affected the brownfields where they were built on, but also all cities and the globe. Intensive migration caused by the industrialization affected urban habitats and floras adversely. Rural population is expected to reach its peak in 2020 as the global rural population is "now close to 3.4 billion and is expected to decline to 3.1 billion by 2050" (As of March 11, 2016, UN reported on its website) [1].

First COP (Conference of Parties) was held in Berlin in 1995 to take precautions against global climate change acts. The developed countries have started to gather annually

* Corresponding author:

cemayik@gmail.com (Cem Ayik)

Published online at http://journal.sapub.org/arch

Copyright (C) 2017 Scientific \& Academic Publishing. All Rights Reserved since then. After two years in 1997 Kyoto Protocol was signed by parties which guaranteed keeping global warming below 2 degrees Celsius and declining GHG emissions. Since then climate reports presented that this aim could not be achieved till 2015. COP21 Paris meeting in 2015 noted this and parties agreed to keep the global warming on 2 degrees Celsius level with taking precautions of $\mathrm{GHG}$ emissions and focusing on renewable energy usages (As of march 14, 2016, Conference of Parties reported on its website) [2].

Sustainable design on architectural scale was the beginning of the sustainable built environment topics. However, there is no at urban level urban sustainability assessment tool. Sustainable design at urban scale is an obvious and immediate need according to recent climatic output data. The recent city formations and reformations have unique situation with this problem. As Einstein contributed this topic with words of 'The significant problems we face cannot be solved at the same level of thinking we used when we created them.', we could not achieve our sustainable goals with our conventional understanding of planning. Innovations in planning and tracing trends of recent achievements should be adopted to these new planning approaches. 


\section{Methodology}

This paper analyses recent years' sustainability researches in terms of urban design and neighboorhood sustainability assessment tools. An in-depth literature review on the recent literature in the field has been carried out. An in-depth literature review can contribute to the solution of the problems and to obtain beneficial synthesis. Although literature review is usually an important part of the studies in most cases, it can also be a stand-alone work [3]. Systematic review is a specific and reproducible approach for identifying, selecting, and appraising all the literature at a certain agreed level of quality that are relevant to a research question (Booth et al., 2012) [4].

Table 1. Systematic approach of the study (Left Side: Literature Research, Right Side: Assessment Tool Research)

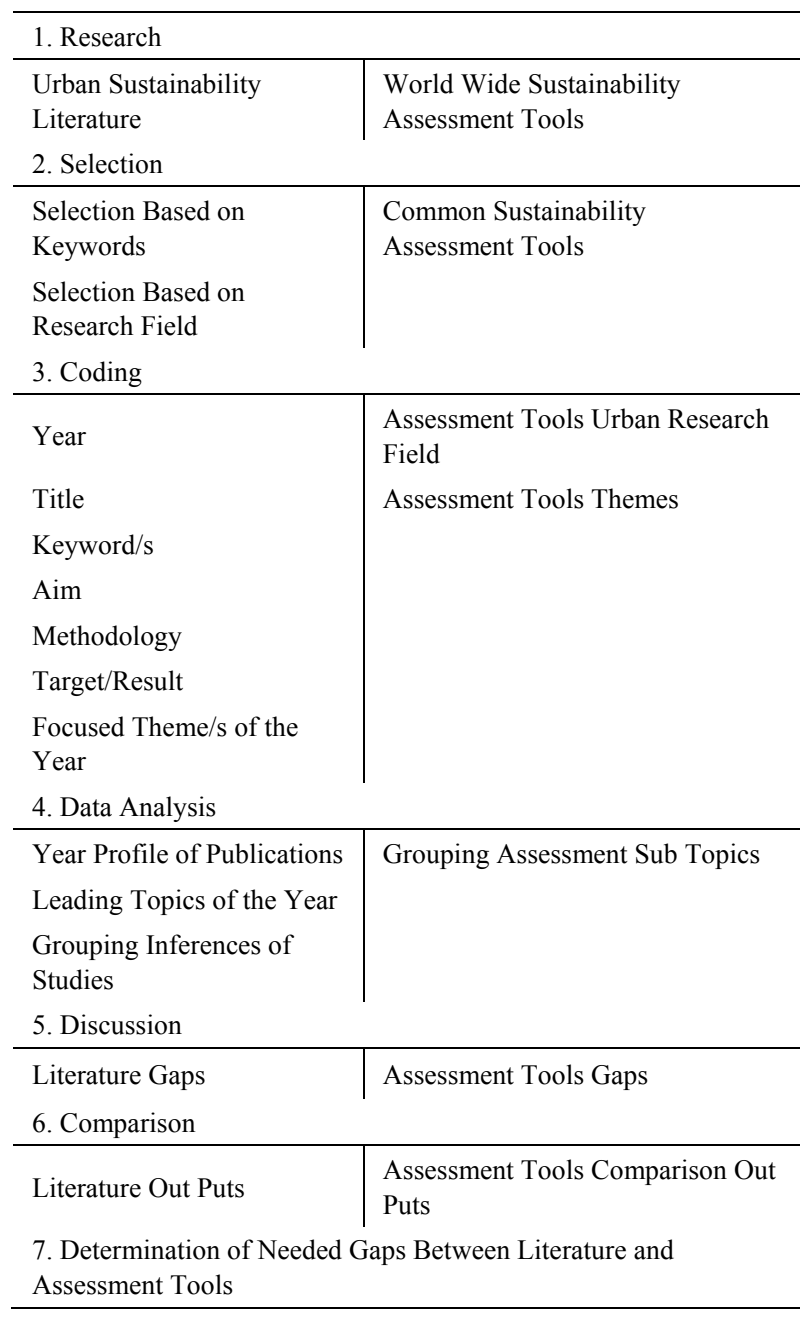

This study adopts the systematic review as a methodological approach to review the existing sustainable urbanization literature to identify knowledge gaps for future research agenda. Table 1 shows the phases of this systematic review phases of this study. Listed seven steps have been followed in this study. The first four steps aim to collect enough data about sustainable urbanization in two columns (Literature and Assessment Tools). Although there are many books written on sustainability, electronic databases (Science Direct Articles) have been examined in terms of recently published articles about urban sustainability. The research topics were then discussed from chronological and thematic perspectives. Research gaps in the literature and assessment tools were identified to guide future studies on sustainable urbanization.

Table 2 shows the first phase of this study. The objective of this review is not to give a comprehensive list of studies but to give an in-depth review of recent trends about sustainable urbanization. 400 articles related with the urban sustainability were examined. A preliminary review was conducted through reading abstracts and keywords of the 400 articles. Two (building scale, construction management studies were eliminated) filter criteria have been applied to select relevant publications for an in-depth review and analysis about urban sustainability. After application of the selection criteria, 200 relevant publications remained. In total 200 publications published between 2000-2015 have been analyzed. Publications have been scanned with 'Sustainable city', 'Smart City' and 'Sustainable Development' keywords. Results have been refined to the publications related with urban sustainability. Table 3 shows the number of articles in related urban study topics. Sustainable built environment studies are more than sustainable studies on energy, environment and ecological studies. The publications provided from Science Direct database at most. Electronic databases are reliable resources in scientific studies like other printed studies. Although there are so many written books, reference works and other works, even in these databases, this study focuses on articles.

Table 2. Chronology of first phase of study

\begin{tabular}{ll}
\hline \multicolumn{1}{c}{ Research phases } & \multicolumn{1}{c}{ Studies } \\
\hline $\begin{array}{l}\text { 1. Literature } \\
\text { Research }\end{array}$ & $\begin{array}{l}\text { Electronic data bases and 35 journals are } \\
\text { identified }\end{array}$ \\
$\begin{array}{l}\text { 2. Literature } \\
\text { Selection }\end{array}$ & $\begin{array}{l}\text { Year periods are determined, related keywords } \\
\text { search is done for } \\
\text { narrated results }\end{array}$ \\
3. Literature Coding & $\begin{array}{l}\text { Publications coded in Year, Title, Keywords, } \\
\text { Aim, Methodology, Target, Journal, Publisher }\end{array}$ \\
4. Data Analysis & $\begin{array}{l}\text { Brief inferences of studies, related year popular } \\
\text { topics, frequencies of same topic research, used } \\
\text { Methods were found out }\end{array}$ \\
5. Discussion & $\begin{array}{l}\text { Inferences of publications formed to be } \\
\text { discussable }\end{array}$ \\
\hline
\end{tabular}

Table 3 shows the distribution of 200 publication from 35 journals under created relevant top topics. The journals in these categories are Procedia Social and Behavioral Sciences (had the largest number of relevant publications (68 publications)), followed by Cities (34 publication), then Landscape and Urban Planning (22 publication), then Renewable and Sustainable Energy Reviews (15 publication). The rest of the journals had the article count equal or less than 10 which indicates $\% 5$ percent and less. 
Table 3. The number of related studies in the relevant top topics

\begin{tabular}{lcc}
\hline \multicolumn{1}{c}{ Relevant top topics of articles } & $\begin{array}{c}\text { Number of } \\
\text { articles }\end{array}$ & Percentage \% \\
\hline $\begin{array}{l}\text { Sustainable Built Environment } \\
\text { Studies }\end{array}$ & 81 & 40,5 \\
$\begin{array}{l}\text { Social Science Sustainability } \\
\text { Studies }\end{array}$ & 69 & 34,5 \\
$\begin{array}{l}\text { Sustainable and Renewable } \\
\text { Energy Studies }\end{array}$ & 29 & 14,5 \\
$\begin{array}{l}\text { Environmental and Ecological } \\
\text { Studies }\end{array}$ & 19 & 9,5 \\
Sustainable Economy Studies & 2 & 1 \\
\hline
\end{tabular}

The title, abstract and keywords of the publications were used for literature coding. When the required information could not be obtained from the title, abstract and keywords, the full publication was evaluated to facilitate coding. The following information was stored in the database during the coding process: publication year of each publication; publication title; publication keywords; research aim; research method; research target; leading themes of the year; journal title.

\section{Results}

\subsection{Publications Distributed by Topics}

Urban studies have been evolved in the recent era due to the environmental changes. While accessibility, governance, ecology and economical perspectives of urban planning are being researched since the very beginning, some new perspectives (e.g. innovation, being local added to sustainable urban planning topics) have been added due to globalization.

Table 4 provides a list of assessment topics obtained from 200 publications. This analysis revealed the needs for more sustainable urban planning.

Assessment topic reference frequencies have been shown in the Figure 1 to emphasize the dominant sustainable topics.

At local level local resource usage and being environmental are among the emphasized topics. At the innovation level it is repeated also so many times in publications that ideas are very important for new inventions. Besides macro and micro ecologies, multidisciplinary work has a significant importance about protecting our environment. At the economic level, it is advocated that foreseeing what the people will consume in the near future and making economical policies based on their attitudes are the basis of the economics' understanding.

\subsection{Publications Annual Distribution}

Publications have been analyzed to determine topics about sustainable urbanization in each year. Figure 2 shows the number of publications per year. Frequencies of the relevant publications have increased in the recent 3 years.

Table 4. Grouping inferences of studies by urban studies and related assessment topics

\begin{tabular}{|c|c|c|c|}
\hline Row & $\begin{array}{l}\text { Urban Study } \\
\text { Topic }\end{array}$ & $\begin{array}{l}\text { Assessment Topic } \\
\text { Code }\end{array}$ & Assessment Topic \\
\hline 1 & Accessibility & Acc1 & Need for a sustainable transportation network and management \\
\hline 2 & & Loc1 & $\begin{array}{l}\text { Need for taking environmental and local properties and energy resources } \\
\text { into account while building }\end{array}$ \\
\hline 3 & Locantity & Loc2 & $\begin{array}{l}\text { Need for taking different scales of public structure and culture into accoun } \\
\text { in terms of sustainability }\end{array}$ \\
\hline 4 & & Loc3 & Need for being sustainably cultural \\
\hline 5 & Innovation & Inn1 & Need of use of innovative ideas, inventions and information technologies \\
\hline 6 & & Inn2 & Need for a more powerful and quantitative sustainability assessment \\
\hline 7 & & Gov1 & Need of policy and management in sustainability \\
\hline 8 & Governance & Gov2 & Need of experience sharing, education and participation \\
\hline 9 & & Gov3 & $\begin{array}{l}\text { Need of taking urban scale into account that has an important role for } \\
\text { sustainability }\end{array}$ \\
\hline 10 & & Ecl1 & Need for multi disciplinary, global, environmental approach and enterprise \\
\hline 11 & Ecology & Ecl2 & Need for sustainable construction, responsive for natural environment \\
\hline 12 & & $\mathrm{Ecl} 3$ & $\begin{array}{l}\text { Need for taking macro and micro economies into account while assessing } \\
\text { sustainability }\end{array}$ \\
\hline 13 & & Ecn1 & $\begin{array}{l}\text { Need for following recent trends, guessing future trends and guessing } \\
\text { problems }\end{array}$ \\
\hline 14 & Economy & Ecn2 & Need for evaluating economic state \\
\hline 15 & & Ecn3 & $\begin{array}{l}\text { Need for taking developing countries and their high population trends and } \\
\text { its importance into account about global sustainability assessments }\end{array}$ \\
\hline
\end{tabular}




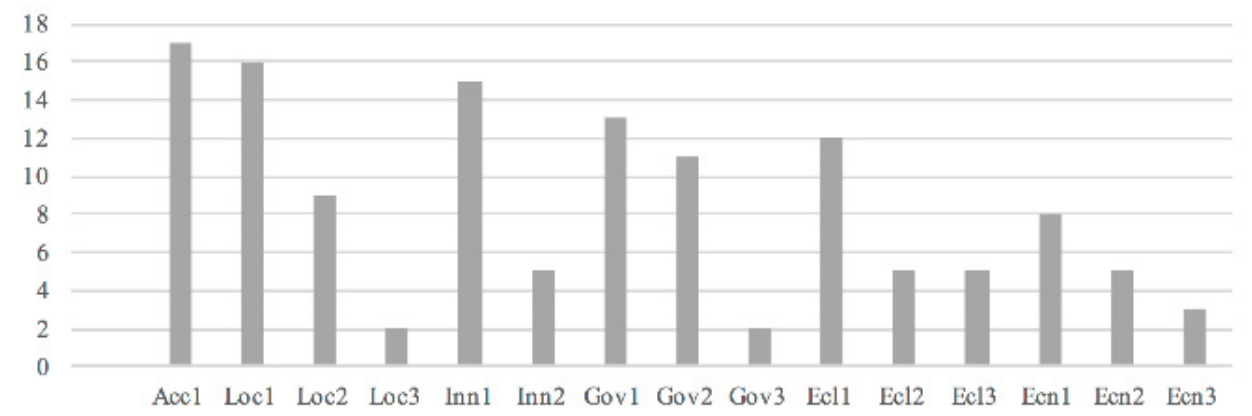

Figure 1. Related reference frequencies

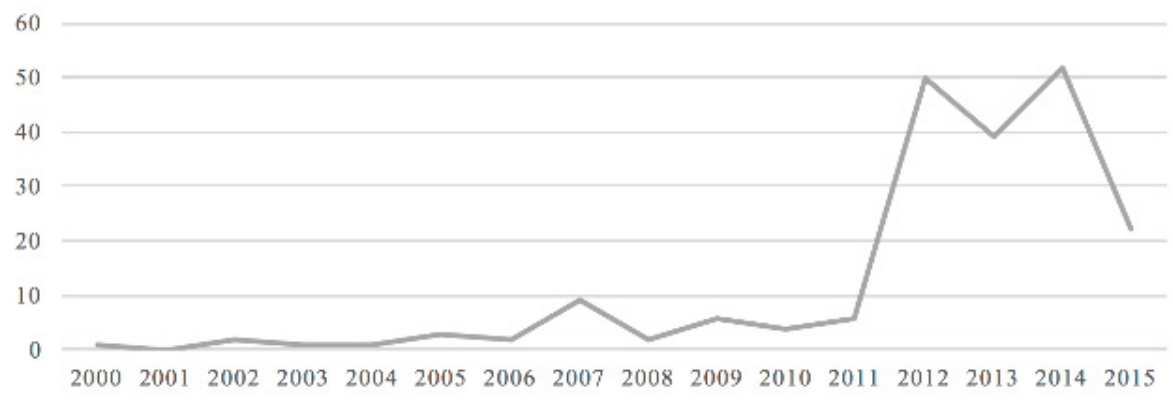

Figure 2. Number of publications per year (till August 2015)

From 2000 to 2015 mostly investigated urban study topics have been analyzed in this phase of the study to understand urban trends and study topics of the recent years.

As seen from the Table 5, sustainable urbanization researches have started to work on energy topic and on building scale from the beginning of 2000. Each year new research topics have been added to research in the field of the sustainable built environment. According to annual topic trends, it is understood that urban policies have changed their scale from macro to micro.

Table 5 shows that from 2000 to 2011 researches $^{1}$ have focused mainly on the energy consumption in the built environment. Although energy is keeping its importance in the environmental sustainability, sustainability topic has been started to be studied focusing on the livability from perspective of quality of citizens' life after $2012^{2}$ intensively. In $2013^{3}$ it is shown that as one of the result of urban sprawl and highly urbanization, peripheral of cities have been effected by the harmed ecologies. Quality of life has been effected adversely due to poor air quality (e.g. in China). After $2014^{4}$, researchers have focused more on policies' and decision making organizations' affects on sustainable built and unbuilt environment. Studies on transportation, logistics and innovations have been intensified after 2014. Educating developing countries besides developed countries became an emphasized topic in the studies in recent years. Furthermore, participation identity became noteworthy subject in $2015 .^{5}$

Table 5. Frequently investigated research topics since 2000 in the field of sustainable urbanization

\begin{tabular}{cl}
\hline Years & \multicolumn{1}{c}{ Leading topics } \\
\hline $2000-2005$ & Energy consume models \\
2006 & Sustainable designs
\end{tabular}

$\begin{array}{ll}2007 & \text { Energy based sustainability } \\ 2008 & \text { Sustainability assessments } \\ 2009 & \text { Debate on sustainability critics } \\ 2011 & \text { Energy based green construction } \\ 2012 & \text { Energy efficient buildings } \\ & \text { Energy assessment of built environment } \\ & \text { Sustainable urbanization } \\ & \text { Public realms } \\ & \text { Macro economies } \\ & \text { Quality of urban realms } \\ & \text { Urban sprawl } \\ & \text { Urban ecosystem } \\ & \text { Urban renewable energies } \\ & \text { Sustainable development } \\ & \text { Urban resilience } \\ & \text { Zero carbon } \\ & \text { Quality of life } \\ & \text { Energy consume } \\ & \text { Sustainable energy policies } \\ & \text { Regional sustainability and social adaptation } \\ & \text { Urban logistics } \\ & \text { Sustainability education } \\ & \text { Future sustainable city models } \\ & \text { Innovation and information techniques } \\ & \text { Assessment of renewable energy resources } \\ & \text { Intelligent Transportation } \\ & \text { Green infrastructure and nature relation } \\ & \text { Comfort and quality of life } \\ & \text { Participation and identity } \\ & \\ 2014 & \\ & \end{array}$




\subsection{Urban Neighbourhood Sustainability Assessment Tool Selection}

Urban sustainability is not a new discussion topic. After the smart city term was unveiled in the urban planning and construction in 1950s, in 1960s the Eco-City term became a popular topic as a result of ecologically destroyed lands in the post industrial revolution period. Afterwards ecological planning came on to table in the following decade. Many precautions had been taken to protect our environment. There were, however, some problems. In 1986 the "Green Washing" (by Jay Westewelt) term took place in the publications. This indicates that there were still problems in achieving a real sustainable environment. One of the mile stones about the sustainability achievement is the Brutland Report "Our Common Future" in 1987. This report announced that sustainability is a common problem which can be solved by global common policies.

After the United States Green Building Council (USGBC) and United Nations Commission of Sustainable Development (UNCSD) were founded in 1993 first neighborhood scale sustainability assessment tool, CASBEE UD (Japan) was launched in 2006. Subsequently LEED ND (USA) in 2009, The Pearl Rating System (Abu Dabi, UAE) in 2010, DGNB NUD (Germany) 2011, Breeam Communities (UK) in 2011 and many other neighborhood sustainability assessment tools were released. In this study world recent top 6 sustainability rating system at urban neighborhood level have been analyzed. The investigated topics in these assessment tools have been analyzed and cross matched between literature review to find gaps that can enlighten and contribute to urban sustainability researches.

\subsection{Sustainability Assessment Tools Criteria Analysis}

Sustainability assessment tools calculate sustainability of architectural and urban planning projects. The six leading sustainability tools and certification systems analyzed in this paper are: LEED ND (USA) [5], Breeam Communities (UK) [6], DGNB NUD (Germany) [7], CASBEE for UD (Japan)
[8], Greenstar Communities (Australia) [9] and Green Mark for Districts (Singapore) [10]. It was paid attention to analyze most recent versions of these tools.

It is noticed that leading assessment tools are released from developed countries. These tools are applicable worldwide. As it is seen in Figure 3 selected tools have different origins.

\section{Discussion}

From the beginning of the second millennium until the end of the first decade, sustainability topic has been mainly focused on the energy topic. Energy efficient building movement spread rapidly throughout the world. While sustainability was a popular topic in the beginning of 2000s, quality of life and participation in cities became more important research topics mainly after 2012. Studies, after 2012, show that education plays a critical role in the public's adaptation of the sustainable approaches and in the success of the policies.

A cross evaluation and check has been performed between literature and assessment tools analysis in this part of this paper. Urban study topics have been listed in the Table 6, and assessment topics cross checks with the assessment tools have been provided in the Table 7 .

Table 6 indicates that the Breeam Communities involves all investigated topics. Locality and ecology topics are concerned by all tools. Accessibility topic takes place among the assessment criteria in all tools except in the Greenstar Communities. DGNB NUD and CASBEE for UD have no innovation criterion.

According to the Table 7, all assessment tools investigated cover intensively the 3 assessment criteria $(1,2,12)$ in Table 4 . The two gaps identified are: the need for taking urban scale into account that has an important role for sustainability and the need for taking developing countries and their high population trends in the global sustainability assessment'.

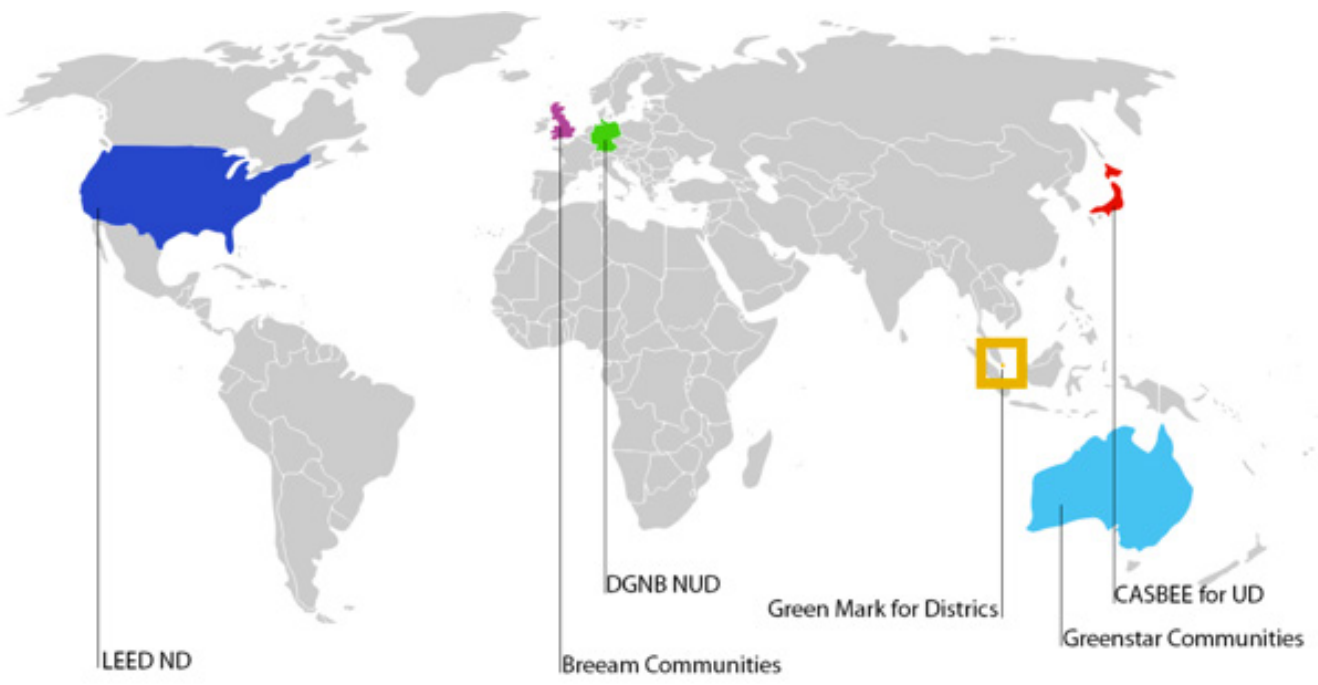

Figure 3. Selected world six leading neighbourhood sustainability assessment tools' geographical locations 
Table 6. Urban study topic comparison between literature review outputs and the urban planning sustainability assessment tools investigated (1: included, 0 : excluded)

\begin{tabular}{|c|c|c|c|c|c|c|}
\hline & USA & UK & Germany & Japan & Australia & Singapore \\
\hline & LEED v4 ND & $\begin{array}{c}\text { Breeam } \\
\text { Communities } \\
2012\end{array}$ & $\begin{array}{l}\text { DGNB NUD } \\
\text { v.2012 }\end{array}$ & $\begin{array}{l}\text { CASBEE for } \\
\text { UD v. } 1.0\end{array}$ & $\begin{array}{c}\text { Greenstar } \\
\text { Communities } \\
\text { v.1.0 }\end{array}$ & $\begin{array}{c}\text { Green Mark } \\
\text { for Districts } \\
\text { v. } 2.0 \\
\end{array}$ \\
\hline Accessibility & 1 & 1 & 1 & 1 & 0 & 1 \\
\hline Locality & 1 & 1 & 1 & 1 & 1 & 1 \\
\hline Innovation & 1 & 1 & 0 & 0 & 1 & 1 \\
\hline Governance & 0 & 1 & 1 & 1 & 1 & 0 \\
\hline Ecology & 1 & 1 & 1 & 1 & 1 & 1 \\
\hline Economy & 0 & 1 & 1 & 0 & 1 & 0 \\
\hline
\end{tabular}

Table 7. Assessment criteria comparison between literature review outputs and the urban planning sustainability assessment tools investigated (\#: related sub topic numbers of assessment tools, 0: excluded)

\begin{tabular}{|c|c|c|c|c|c|c|}
\hline & USA & UK & Germany & Japan & Australia & Singapore \\
\hline $\begin{array}{l}\text { Related row number } \\
\text { in Table } 5\end{array}$ & LEED v4 ND & $\begin{array}{l}\text { Breeam Communities } \\
2012\end{array}$ & $\begin{array}{l}\text { DGNB NUD } \\
\text { v. } 2012\end{array}$ & $\begin{array}{c}\text { CASBEE for UD } \\
\text { v. } 1.0\end{array}$ & $\begin{array}{c}\text { Greenstar } \\
\text { Communities } \\
\text { v.1.0 }\end{array}$ & $\begin{array}{c}\text { Green Mark for } \\
\text { Districts v. } 2.0\end{array}$ \\
\hline 1 & 12 & 9 & 7 & 23 & 3 & 3 \\
\hline 2 & 11 & 13 & 19 & 21 & 3 & 14 \\
\hline 3 & 0 & 1 & 2 & 1 & 3 & 0 \\
\hline 4 & 1 & 0 & 1 & 0 & 0 & 0 \\
\hline 5 & 7 & 1 & 0 & 8 & 3 & 9 \\
\hline 6 & 0 & 0 & 0 & 0 & 0 & 1 \\
\hline 7 & 0 & 5 & 7 & 9 & 2 & 1 \\
\hline 8 & 3 & 0 & 2 & 3 & 7 & 2 \\
\hline 9 & 0 & 0 & 0 & 0 & 0 & 0 \\
\hline 10 & 1 & 0 & 0 & 0 & 0 & 0 \\
\hline 11 & 9 & 1 & 0 & 9 & 0 & 2 \\
\hline 12 & 6 & 8 & 5 & 12 & 6 & 5 \\
\hline 13 & 0 & 1 & 2 & 0 & 4 & 1 \\
\hline 14 & 1 & 2 & 0 & 0 & 1 & 0 \\
\hline 15 & 0 & 0 & 0 & 0 & 0 & 0 \\
\hline
\end{tabular}

\section{Conclusions}

Cities are living complex entities built up by human beings. As Herbert Girardet says in his work on Cities and Sustainability 'currently cities are not centres of civilisation but mobilisation of people and goods' [11]. Nevertheless, more researches should be concentrated on this complexity to find solutions about how to live more sustainable in cities.

This paper provided trends in the recent years' sustainability researches in terms of urban design. According to investigated studies more participated and multi disciplinary understanding urban design and planning with support of innovations are adviced.

This paper also provided analysis about the neighboorhood sustainability assessment tools. Assessment tools' scale and scope need to cover urban scale sustainability. Neighbourhood scale studies are not common as the studies at the building scales. The main reason might be the complexities of the cities. Creating a comprehensive and ultimate city scale sustainability tool is not an easy task to achieve. As studies mention local properties, citizens' attitudes and their life habits affect their sustainability performance. Instead of trying to explore or invent one acceptable approach for a sustainable development, local sustainable tools at urban levels should be studied. This study has identified two gaps, namely: the need for taking urban scale into account that has an important role for sustainability and the need for taking developing countries and their high population trends in the global sustainability assessment'. These two point should be taken into account by first key actors, governments. As also Jorgen Sanders emphasizes on governing 'Most of the solutions to today's global problems exist, and the only reason they're not implemented is that we don't have strong government' [12].

It is suggested that the findings of this study can contribute to planners and policy makers in creating more sustainable 
cities. Further studies are recommended to be carried out on sustainability education and on. encouraging citizens to live and behave sustainably

\section{ACKNOWLEDGEMENTS}

This study is a part of continuing Ph.D. study in the Urban and Regional Planning Program at Istanbul Technical University.

\section{Notes}

1. Studies published in 2000-2011 and listed in the bibliography part of this study

2. Studies published in 2012 and listed in the bibliography part of this study

3. Studies published in 2013 and listed in the bibliography part of this study

4. Studies published in 2014 and listed in the bibliography part of this study

5. Studies published in 2015 and listed in the bibliography part of this study

\section{REFERENCES}

[1] http://www.un.org/en/development/desa/news/population/wo rld-urbanization-prospects-2014.html $\quad 11.03 .2016 \quad 17: 16$ $(\mathrm{GMT}+2)$

[2] http://www.cop21paris.org/about/cop21/ 14.03.2016 12:40 $(\mathrm{GMT}+2)$

[3] Zhou, Zhipeng, Yang Miang Goh, and Qiming Li. "Overview and analysis of safety management studies in the construction industry." Safety Science 72, (2015): 337-350. doi:10.1016/j.ssci.2014.10.006.

[4] Booth, A., Papaioannou, D., Sutton, A., 2012. Systematic Approaches to a Successful Literature Review. SAGE Publications Ltd., Thousand Oaks, CA, United States.

[5] LEED v4 for Neighborhood Development Built Project

[6] Breeam Communities:Technical Manual: SD202 Version: 2012 Issue: 0.1 Issue Date: 21/02/2013

[7] DGNB New Urban Districts (NUD/NSQ) v.2012

[8] CASBEE for Urban Development (2007 Edition) v.1.0 City-center Type

[9] Greenstar Communities v.1.0 2015

[10] BCA Green Mark for Districts v.2.0

[11] Girardet, H. (1999) Creating Sustainable Cities. Totnes: Green Books.

[12] Sanders, J. (2012) 2052: A global forecast for the next forty years, Chelsea Green Publishing

\section{BIBLIOGRAPHY / PUBLICATIONS ANALYZED}

[1] Abdel-Hadi, Aleya. "Culture, Quality of life, Globalization and Beyond." Procedia Social and Behavioral Sciences 50, (2012): 11-19. doi:10.1016/j.sbspro.2012.08.011.

[2] Abdullah, Nuraisyah Chua. "Going Green in Urbanisation Area: Environmental alternative dispute resolution as an option." Procedia Social and Behavioral Sciences 170, (2015): 401-408. doi:10.1016/j.sbspro.2015.01.050.

[3] Ahern, Jack, Sarel Cilliers, and Jari Niemelä. "The concept of ecosystem services in adaptive urban planning and design: A framework for supporting innovation." Landscape and Urban Planning 125, (2014): 254-259.

doi:10.1016/j.landurbplan.2014.01.020.

[4] Akgun, Aliye Ahu, Eveline van Leeuwen, and Peter Nijkamp. "A multi-actor multi-criteria scenario analysis of regional sustainable resource policy." Ecological Economics 78, (2012): 19-28. doi:10.1016/j.ecolecon.2012.02.026.

[5] Akhmat, Ghulam, Khalid Zaman, Tan Shukui, and Faiza Sajjad. "Does energy consumption contribute to climate change? Evidence from major regions of the world." Renewable and Sustainable Energy Reviews 36, (2014): 123-134. doi: 10.1016/j.rser.2014.04.044.

[6] Ambarwati, Lasmini, Robert Verhaeghe, Adam J. Pel, and Bart van Arem. "Controlling Urban Sprawl with Integrated Approach of Space-Transport Development Strategies." Procedia Social and Behavioral Sciences 138, (2014): 679-694. doi:10.1016/j.sbspro.2014.07.261.

[7] Anand, Nilesh, Hans Quak, Ron van Duin, and Lori Tavasszy. "City logistics modeling efforts: Trends and gaps - A review." Procedia Social and Behavioral Sciences 39, (2012): 101-115. doi:10.1016/j.sbspro.2012.03.094.

[8] Angelidou, Margarita. "Smart city policies: A spatial approach." Cities 41, (2014): 3-11. doi:10.1016/j.cities.2014.06.007.

[9] Anghela, Alina Gabriela, Luminita Mihaela Drăghicescu, Gabriela Cătălina Cristea, Gabriel Gorghiu, Laura Monica Gorghiu, and Ana-Maria Petrescu. "The Social Knowledge: A Goal of the Social Sustainable Development." Procedia Social and Behavioral Sciences 149, (2014): 43-49. doi:10.1016/j.sbspro.2014.08.187.

[10] Asilsoy, Buket. "A survey study on environmental consciousness in Famagusta." Procedia Social and Behavioral Sciences 35, (2012): 675-681. doi:10.1016/j.sbspro.2012.02.136.

[11] Aydin, Gokhan. "Modeling of energy consumption based on economic and demographic factors: The case of Turkey with projections." Renewable and Sustainable Energy Reviews 35, (2014): 382-389. doi: 10.1016/j.rser.2014.04.004.

[12] Baba, Adams Ndalai, Nooraini Binti Yusoff, and Emmanuel O. F. Elegbac. "Towards cities inclusiveness: the land use paradigm option for Nigeria." Procedia Social and Behavioral Sciences 172, (2015): 367-374. doi:10.1016/j.sbspro.2015.01.381.

[13] Bahadori, Alireza, Chikezie Nwaoha, Sohrab Zendehboudi, and Gholamreza Zahedi. "An overview of renewable energy 
potential and utilisation in Australia." Renewable and Sustainable Energy Reviews 21, (2013): 582-589. doi:10.1016/j.rser.2013.01.004.

[14] Ballas, Dimitris. "What makes a 'happy city'?" Cities 32, (2013): 39-50. doi:10.1016/j.cities.2013.04.009.

[15] Barthel Stephan, and Christian Isendahl. "Urban gardens, agriculture, and water management: Sources of resilience for long-term food security in cities." Ecological Economics, v.86, (2013): 224-234. doi:10.1016/j.ecolecon.2012.06.018.

[16] Bartkowski, Bartosz, Nele Lienhoop, and Bernd Hansjürgens. "Capturing the complexity of biodiversity: A critical review of economic valuation studies of biological diversity." Ecological Economics 113, (2015): 1-14. doi:10.1016/j.ecolecon.2015.02.023.

[17] Baura, Joshua W.R., Joanne F. Tynon, and Edwin Gómez. "Attitudes about urban nature parks: A case study of users and nonusers in Portland, Oregon." Landscape and Urban Planning 117, (2013): 100-111. doi:10.1016/j.landurbplan.2013.04.015.

[18] Bayulken, Bogachan, and Donald Huisingh. "A literature review of historical trends and emerging theoretical approaches for developing sustainable cities (part 1).” Journal of Cleaner Production 109 (2015): 11-24. doi:10.1016/j.jclepro.2014.12.100.

[19] Behrendsa, Sönke. "The urban context of intermodal road-rail transport - Threat or opportunity for modal shift?" Procedia Social and Behavioral Sciences 39, (2012): 463-475. doi:10.1016/j.sbspro.2012.03.122.

[20] Berkoz Lale. "The Interregional Location of Foreign Investors in Turkey." European Planning Studies 9, no. 8, (2010): 979-994. doi:10.1080/09654310120093304.

[21] Berkoz, Lale, and Engin Eyuboglu. "Intrametropolitan Location of Producer-service FDI in Istanbul." European Planning Studies 15, no. 3 (2007): 357-381. doi:10.1080/09654310601017075.

[22] Berkoz, Lale, Sevkiye Sence Turk, and OOmer L. Kellekci. "Environmental Quality and User Satisfaction in Mass Housing Areas: The Case of Istanbul." European Planning Studies 17, no. 1 (2008): 161-164. doi:10.1080/09654310802514086.

[23] Berkozg Lale. "Locational preferences of producer service firms in Istanbul." European Planning Studies 6, no. 3 (2007): 333-349. doi:10.1080/09654319808720465.

[24] Bšhringer, Christoph, and Patrick E.P. Jochem. "Measuring the immeasurable - A survey of sustainability indices." Ecological Economics 63, (2007): 1-8. doi:10.1016/j.ecolecon.2007.03.008.

[25] Byrne, John, Job Taminiau, Lado Kurdgelashvili, and Kyung Nam Kim. "A review of the solar city concept and methods to assess rooftop solar electric potential, with an illustrative application to the city of Seoul." Renewable and Sustainable Energy Reviews 41, (2015): 830-844. doi:10.1016/j.rser.2014.08.023.

[26] Caprotti, Federico. "Critical research on eco-cities? A walk through the Sino-Singapore Tianjin Eco-City, China." Cities 36, (2014): 10-17. doi:10.1016/j.cities.2013.08.005.
[27] Carpio-Pinedoa, José, Javier Aldecoa Martínez-Conde, and Francisco Lamíquiz Daudéna. "Mobility and Urban Planning Integration at City-Regional level in the Design of Urban Transport Interchanges (EC FP7 NODES Project - Task 3.2.1.)." Procedia Social and Behavioral Sciences 160, (2014): 224-233. doi:10.1016/j.sbspro.2014.12.134.

[28] Castillo-Manzano, José I., Lourdes López-Valpuesta, and Manuel Marchena-Gómez. "Seville: A city with two souls." Cities 42, (2015): 142-151. doi:10.1016/j.cities.2014.10.005.

[29] Cerovsek, Tomo. "A review and outlook for a 'Building Information Model' (BIM): A multi-standpoint framework for technological development." Advanced Engineering Informatics 25, (2011): 224-244.

doi:10.1016/j.aei.2010.06.003.

[30] Chandela, Shyam S., and Amitava Sarkarb. "Performance assessment of a passive solar building for thermal comfort and energy saving in a hilly terrain of India." Energy and Buildings 86, (2015): 873-885. doi:10.1016/j.enbuild.2014.10.035.

[31] Chen, Wendy Y. "The role of urban green infrastructure in offsetting carbon emissions in 35 major Chinese cities: A nationwide estimate." Cities 44, (2015): 112-120. doi:10.1016/j.cities.2015.01.005.

[32] Cheng, Jianquan Luca Bertolini, Frank le Clercq, and Loek Kapoen. "Understanding urban networks: Comparing a node-, a density- and an accessibility-based view." Cities 31, (2013): 165-176. doi:10.1016/j.cities.2012.04.005.

[33] Childers, Daniel L., Steward T.A. Pickett, J. Morgan Grove, Laura Ogden and Alison Whitmer. "Advancing urban sustainability theory and action: Challenges and opportunities." Landscape and Urban Planning 125, (2014): 320-328. doi:10.1016/j.landurbplan.2014.01.022.

[34] Chrysochooua, Maria, Kweku Brown, Geeta Dahal, Catalina Granda-Carvajal, Kathleen Segerson, Norman Garrick, and Amvrossios Bagtzoglou. "A GIS and indexing scheme to screen brownfields for area-wide redevelopment planning." Landscape and Urban Planning 105, (2012): 187-198. doi:10.1016/j.landurbplan.2011.12.010.

[35] Chrysoulakis, Nektarios Myriam Lopes, Roberto San José, Christine Susan Betham Grimmond, Mike B. Jones, Vincenzo Magliulo, Judith E.M. Klostermann, et al. "Sustainable urban metabolism as a link between bio-physical sciences and urban planning: The BRIDGE project." Landscape and Urban Planning 112, (2013): 100-117. doi:10.1016/j.landurbplan.2012.12.005.

[36] Cohen, Marianne, Raymond Baudoin, Milena Palibrk, Nicolas Persyn, and Catherine Rhein. "Urban biodiversity and social inequalities in built-up cities: New evidences, next questions. The example of Paris, France." Landscape and Urban Planning 106, (2012): 277-287. doi:10.1016/j.landurbplan.2012.03.007.

[37] Colding, Johan, and Stephan Barthel. "The potential of 'Urban Green Commons' in the resilience building of cities." Ecological Economics 86, (2013): 156-166. doi:10.1016/j.ecolecon.2012.10.016.

[38] Collier, Marcus J., Zorica Nedovic'-Budic', Jeroen Aerts, Stuart Connop, Dermot Foley, Karen Foley, Darryl Newport, Siobhán McQuaid, Aleksander Slaev, and Peter Verburg. 
"Transitioning to resilience and sustainability in urban communities" Cities 32, (2013) 21-28.

doi:10.1016/j.cities.2013.03.010.

[39] Coppola, Pierluigi, Enrica Papa, Gennaro Angiello, and Gerardo Carpentieri. "Urban Form and Sustainability: The Case Study of Rome." Procedia Social and Behavioral Sciences 160, (2014): 557-566. doi:10.1016/j.sbspro.2014.12.169.

[40] Davies, Jonathan S., and Lindiwe G. Msengana-Ndlela. "Urban power and political agency: Reflections on a study of local economic development in Johannesburg and Leeds." Cities 44, (2014): 131-138. doi:10.1016/j.cities.2014.09.001.

[41] Debnath Ashim Kumar, Hoong Chor Chin, Md. Mazharul Haque, and Belinda Yuen. "A methodological framework for benchmarking smart transport cities." Cities 37, (2014): 47-56. doi:10.1016/j.cities.2013.11.004.

[42] Decker, Christopher S., and Mark E. Wohar. "Substitutability or complementarity? Re-visiting Heyes' IS-LM-EE model." Ecological Economics 74, (2012): 3-7. doi:10.1016/j.ecolecon.2011.12.010.

[43] Diyar, Sabit, Aigul Akparova, Azamat Toktabayev, and Marina Tyutunnikova. "Green Economy - Innovation-Based Development of Kazakhstan." Procedia Social and Behavioral Sciences 140, (2014): 695-699. doi:10.1016/j.sbspro.2014.04.497.

[44] Dogaru, Lucretia. "The importance of environmental protection and sustainable development." Procedia Social and Behavioral Sciences 93, (2013): 1344-1348. doi:10.1016/j.sbspro.2013.10.041.

[45] Douglas, Ian. "The political filter in the local implementation of initiatives relating to urban ecology." Landscape and Urban Planning 125, (2014): 312-319. doi:10.1016/j.landurbplan.2014.02.008.

[46] Duana, Manzhen, Hongying Ya, Lin Zhanga, and Hongmei Jiaa. "Traffic safety analysis of intersections between the residential entrance and urban road." Procedia Social and Behavioral Sciences 96, (2013): 1001-1007. doi:10.1016/j.sbspro.2013.08.114.

[47] Dui, Neven, Krzysztof Urbaniec, and Donald Huisingh. "Components and structures of the pillars of sustainability." Journal of Cleaner Production 88, (2015): 1-12. doi:10.1016/j.jclepro.2014.11.030.

[48] Dursun, Bahtiyar, and Cihan Gokcol. "Impacts of the renewable energy law on the developments of wind energy in Turkey." Renewable and Sustainable Energy Reviews 40, (2014): 318-325. doi:10.1016/j.rser.2014.07.185.

[49] Editorial. "Actionable urban ecology in China and the world: Integrating ecology and planning for sustainable cities." Landscape and Urban Planning 125, (2014): 207-208. doi:10.1016/j.landurbplan.2014.02.022.

[50] Eicker, Ursula, Aneta Strzalka, Tobias Erhart, and Jose Antonio Perrella Balestieri. "Low Energy City Quarters with High Renewable Fractions: Monitoring Results and Potential for Replication." International Journal of Sustainable Building Technology and Urban Developlement 2, no. 1 (2011): 69-80.

https://www.hft-stuttgart.de/Forschung/Kompetenzen/zafh/P ublikationen/publikationen_download/2011/Eicker_Strzalka
_Erhart_Balestieri_Sustainable_Building_Technology_2011. pdf.

[51] Eliasson, Ingegaérd. "The use of climate knowledge in urban planning." Landscape and Urban Planning 48, (2000): 31-44. doi:10.1016/S0169-2046(00)00034-7.

[52] Elshatera, Abeer M., and Fatima Ibraheem. "From Typology Concept to Smart Transportation Hub." Procedia Social and Behavioral Sciences, 153, (2014): 531-541. doi:10.1016/j.sbspro.2014.10.086.

[53] Ercoskun, Özge Yalıner. "Sustainable City Plans Against Development Plans." Gazi University Journal of Science 18, no. 3 (2005): 529-544. gujs.gazi.edu.tr/article/download/1060000492/1060000287.

[54] Ergun, Nilgun, and Bulent Dundar "Functional change as an indicator of transformation near the old city centre of Istanbul." European Planning Studies 12, no. 5 (2010): 723-738. doi:10.1080/0965431042000220048.

[55] Ergun, Nilgun, and Ozge Iskender. "Gardens of the Topkap1 Palace: an example of Turkish garden art." Studies in the History of Gardens \& Designed Landscapes: An International Quarterly 23, no. 1 (2012): 55-71. doi:10.1080/14601176.2003.10435281.

[56] Ergun, Nilgun. “Gentrification in Istanbul.” Cities 21, (2004): 391-405. doi:10.1016/j.cities.2004.07.004.

[57] Ergun, Nilgün, and Funda Yirmibeşoğlu, "Distribution of Crime Rates in Different Districts in Istanbul." Turkish Studies 8, no. 3 (2007): 435-455. doi: $10.1080 / 14683840701489324$.

[58] Eryildiz, Semih, and Klodjan Xhexhi. "Eco Cities" Under Construction." Gazi University Journal of Science 25, no. 1 (2012): 257-261. http://gujs.gazi.edu.tr/article/view/1060000811/1060000564

[59] Eusuf, Muhammad Abu, Mohammad A. Mohit, MMR Sami Eusuf, and Mansor Ibrahim. "Impact of Outdoor Environment to the Quality of Life." Procedia Social and Behavioral Sciences 153, (2014): 639-654. doi:10.1016/j.sbspro.2014.10.096.

[60] Eyüboglu, Engin, Ayse Sema Kubat, and Ozhan Ertekin. “A New Urban Planning Approach for the Regeneration of an Historical Area within Istanbul's Central Business District." Journal of Urban Design 12. no. 2 (2007): 295-312. doi:10.1080/13574800701306179.

[61] Fernandes, José Rio, and Pedro Chamusca. "Urban policies, planning and retail resilience." Cities 36, (2014): 170-177. doi:10.1016/j.cities.2012.11.006.

[62] Ferreira, José Antunes, and Beatriz Condessa. "Defining expansion areas in small urban settlements - An application to the municipality of Tomar (Portugal)." Landscape and Urban Planning 107, (2012): 283-292. doi:10.1016/j.landurbplan.2012.06.008.

[63] Ferri, Barbara, and Antonio Maturo. "Knowing the urban landscape for a sustainable environmental planning in Pescara city." Procedia Social and Behavioral Sciences 46, (2012): 5257-5264. doi:10.1016/j.sbspro.2012.06.418.

[64] Fioretti, Roberto, Anna Palla, Luca G. Lanza, and Paolo Principi. "Green roof energy and water related performance in 
the Mediterranean climate.” Building and Environment 45, (2010): 1890-1904. doi:10.1016/j.buildenv.2010.03.001.

[65] Frame Bob, and Jo Cavanagh. "Experiences of sustainability assessment: An awkward adolescence." Accounting Forum 33, (2009): 195-208. doi:10.1016/j.accfor.2008.07.007.

[66] Freitas, Sara, Cristina M. S. Catita, Paula Redweik, and Miguel Centeno Brito. "Modelling solar potential in the urban environment: State-of-the-art review." Renewable and Sustainable Energy Reviews 41, (2015): 915-931. doi:10.1016/j.rser.2014.08.060.

[67] Fujimori, Shinichiro, and Yuzuru Matsuoka. "Development of method for estimation of world industrial energy consumption and its application." Energy Economics 33, (2011): 461-473. doi:10.1016/j.eneco.2011.01.010.

[68] Gabitov, Tursyn, Ainur Kurmanalieva, Birzhan Moldagaliyev, Zatov Kairat Aytbekovich, and Shugyla Kilybayeva. "Sustainable development as a priority of contemporary cultural policy." Procedia Social and Behavioral Sciences140, (2014): 691-694. doi:10.1016/j.sbspro.2014.04.496.

[69] Gago, Eulalia Jadraque, Julio Roldan, Rosalía. Pacheco-Torres, and Javier Ordóñez. "The city and urban heat islands: A review of strategies to mitigate adverse effectsç" Renewable and Sustainable Energy Reviews 25, (2013): 749-758. doi:10.1016/j.rser.2013.05.057.

[70] Gardrata, Mathieu, Marc Serougea, Florence Toilier, and Jesus Gonzalez-Feliua. "Simulating the Structure and Localization of Activities for Decision Making and Freight Modelling: The SIMETAB Model." Procedia Social and Behavioral Sciences 125, (2014): 147-158. doi:10.1016/j.sbspro.2014.01.1463.

[71] Gezici, Ferhan, and Geoffrey J. D. Hewings. "Spatial Analysis of Regional Inequalities in Turkey." European Planning Studies 15, no. 3 (2007): 383-403. doi: 10.1080/09654310601017091.

[72] Gezici, Ferhan. "Components Of Sustainability Two Cases from Turkey." Annals of Tourism Research 33, (2006): 442-455. doi:10.1016/j.annals.2005.11.002.

[73] Ghaffarian Hoseini, Amir Hosein, Nur Dalilah Dahlan, Umberto Berardi, Ali Ghaffarian Hoseini, Nastaran Makaremi, and Mahdiar Ghaffarian Hoseini. "Sustainable energy performances of green buildings: A review of current theories, implementations and challenges." Renewable and Sustainable Energy Reviews 25, (2013): 1-17. doi:10.1016/j.rser.2013.01.010.

[74] Ghisetti, Claudia, and Francesco Quatraro. "Beyond inducement in climate change: Does environmental performance spur environmental technologies? A regional analysis of cross-sectoral differences." Ecological Economics 96, (2013): 99-113. doi:10.1016/j.ecolecon.2013.10.004.

[75] Gilderbloom, John I., William W. Riggs, and Wesley L. Meares. "Does walkability matter? An examination of walkability's impact on housing values, foreclosures and crime." Cities 42, (2015): 13-24. doi:10.1016/j.cities.2014.08.001.

[76] Gómez-Baggethun, Erik, and David N. Barton. Classifying and valuing ecosystem services for urban planning." Ecological Economics 86, (2013): 235-245. doi:10.1016/j.ecolecon.2012.08.019.
[77] Großmann, Katrin, Marco Bontje, Annegret Haase, and Vlad Mykhnenko. "Shrinking cities: Notes for the further research agenda." Cities 35, (2013): 221-225. doi:10.1016/j.cities.2013.07.007.

[78] Gupta, Kshama, P. Kumar, Subhan Khan Pathan, and Kamesh Prasad Sharma. "Urban Neighborhood Green Index - A measure of green spaces in urban areas." Landscape and Urban Planning 105, (2012): 325-335.

doi:10.1016/j.landurbplan.2012.01.003.

[79] Haapio, Appu. "Towards sustainable urban communities." Environmental Impact Assessment Review 32, (2012): 165-169. doi:10.1016/j.eiar.2011.08.002.

[80] Harun, Nor Zalina, Khalilah Zakariya, Mazlina Mansor, and Khairunnisa Zakaria. "Determining Attributes of Urban Plaza for Social Sustainability." Procedia Social and Behavioral Sciences 153, (2014): 606-615. doi:10.1016/j.sbspro.2014.10.093.

[81] Hosgor Zerrin, and Reyhan Yigiter. "Greenway Planning Context in Istanbul- Haliç: A Compulsory Intervention into the Historical Green Corridors of Golden Horn." Landscape Research 36. No. 3 (2011): 341-361. doi:10.1080/01426397.2011.555529.

[82] Hussain, Yasmin Sofia, and Ismail Said. "Knowledge Integration between Planning and Landscape Architecture in Contributing to a Better Open Space.” Procedia Social and Behavioral Sciences 170, (2015): 545-556. doi:10.1016/j.sbspro.2015.01.056.

[83] Inceoglu Mehmet, and Ayfer Aytug. "Kentsel Mekanda Kalite Kavramı The Concept of Urban Space Quality." Megaron 4, no.3 (2009): 131-146.

http://www.journalagent.com/megaron/pdfs/MEGARON_4 3_131_146.pdf

[84] Irimiea, Sabin-Ioan, Jozsef Galb, and Constantin Dan Dumitrescua. "Analysis of a dynamic regional system for the operationalizing of the sustainable development concept." Procedia Social and Behavioral Sciences 124, (2014): 331-338. doi:10.1016/j.sbspro.2014.02.493.

[85] Jabareen, Yosef. "Planning the resilient city: Concepts and strategies for coping with climate change and environmental risk." Cities 31, (2013): 220-229. doi:10.1016/j.cities.2012.05.004.

[86] Jaffal, Issa, Salah-Eddine Ouldboukhitine, and Rafik Belarbi. "A comprehensive study of the impact of green roofs on building energy performance." Renewable Energy 43, (2012): 157-164. doi:10.1016/j.renene.2011.12.004.

[87] Jain, Uday. "Cultural Construction of Environmental Problems." Procedia Social and Behavioral Sciences 68, (2012): 6-15. doi:10.1016/j.sbspro.2012.12.202.

[88] Jalaladdini, Siavash, and Derya Oktay. "Urban Public Spaces and Vitality: A Socio-Spatial Analysis in the Streets of Cypriot Towns." Procedia Social and Behavioral Sciences 35, (2012): 664-645. doi:10.1016/j.sbspro.2012.02.135.

[89] Jedliński, Mariusz. "The position of green logistics in sustainable development of a smart green city." Procedia Social and Behavioral Sciences 151, (2014): 102-111. doi:10.1016/j.sbspro.2014.10.011.

[90] Juceicius, Giedrius, and Kristina Grumadaite. "Smart 
development of innovation ecosystem." Procedia Social and Behavioral Sciences 156, (2014): 125-129. doi:10.1016/j.sbspro.2014.11.133.

[91] Juceviius, Robertas, Irena Patašien, and Martynas Patašius. "Digital dimension of smart city: critical analysis." Procedia Social and Behavioral Sciences, 156, (2014): 146-150. doi:10.1016/j.sbspro.2014.11.137 .

[92] Karagulle, Can, and Yuksel Demir. "Yerel verilerin konut tasarım sürecinde değerlendirilmesi: Mardin örneği." $\begin{array}{lllll}\text { itüdergisi/a } & 9 \text {, no. } & 2 & \text { (2010): 83-94. }\end{array}$ http://itudergi.itu.edu.tr/index.php/itudergisi_a/article/viewFi le/1054/1006

[93] Kardosa, Mihaela. "The reflection of good governance in sustainable development strategies." Procedia Social and Behavioral Sciences 58, (2012): 1166-1173. doi:10.1016/j.sbspro.2012.09.1098.

[94] Kaygusuz, Asim, Cemal Keles, Baris Baykant Alagoz, and Abdulkerim Karabiber. "Renewable energy integration for smart sites." Energy and Buildings 64, (2013): 456-462. doi:10.1016/j.enbuild.2013.05.031.

[95] Keirstead, James, Mark Jennings, and Aruna Sivakumar. “A review of urban energy system models: Approaches, challenges and opportunities." Renewable and Sustainable Energy Reviews 16, (2012): 3847-3866. doi:10.1016/j.rser.2012.02.047

[96] Keleş Sedat, and Selçuk Bilgen. "Renewable energy sources in Turkey for climate change mitigation and energy sustainability." Renewable and Sustainable Energy Reviews 16, (2012): 5199-5206. doi:10.1016/j.rser.2012.05.026.

[97] Kellekci, Omer Lutfi, and Lale Berkoz. "Mass Housing: User Satisfaction in Housing and its Environment in Istanbul, Turkey." International Journal of Housing Policy 6, no.1 (2007): 77-99. doi:10.1080/14616710600587654.

[98] Kellett, Ronald, Andreas Christen, Nicholas C. Coops, Michael van der Laan, Ben Crawford, Thoreau Rory Tooke, and Inna Olchovski. "A systems approach to carbon cycling and emissions modeling at an urban neighborhood scale." Landscape and Urban Planning 110, (2013): 48-58. doi:10.1016/j.landurbplan.2012.10.002.

[99] Kirby, Andrew. "Current Research on Cities and its contribution to urban studies." Cities 29, (2012): 3-8. doi:10.1016/j.cities.2011.12.004

[100] Kyttä, Marketta, Anna Broberg, Tuija Tzoulas, and Kristoffer Snabb. "Towards contextually sensitive urban densification: Location-based softGIS knowledge revealing perceived residential environmental quality." Landscape and Urban Planning 113, (2013): 30-46. doi: 10.1016/j.landurbplan.2013.01.008.

[101] Lamíquiz-Daudéna, Francisco J., José Carpio-Pinedo, and Antonio García-Pastor. "Transport interchange and local urban environment integration." Procedia Social and Behavioral Sciences 160, (2014): 215-223. doi: 10.1016/j.sbspro.2014.12.133.

[102] Latif, Saripah Abdul, Mohd Shukri Omar, Yeop Hussin Bidin and Zainudin Awang. "Environmental Values as a Predictor of Recycling Behaviour in Urban Areas: A Comparative Study." Procedia Social and Behavioral Sciences 50, (2012): 989-996. doi:10.1016/j.sbspro.2012.08.100.
[103] Latif, Saripah Abdul, Mohd Shukri Omar, Yeop Hussin Bidin, and Zainudin Awang. "Role of Environmental Knowledge in Creating Pro-Environmental Residents." Procedia Social and Behavioral Sciences 105, (2013): 866-874. doi:10.1016/j.sbspro.2013.11.088.

[104] Liu, Shih-Yuan, Yeng-Horng Perng, and Yu-Feng Ho. "The effect of renewable energy application on Taiwan buildings: What are the challenges and strategies for solar energy exploitation?" Renewable and Sustainable Energy Reviews 28, (2013): 92-106. doi:10.1016/j.rser.2013.07.018.

[105] MacKillop, Fionn. "Climatic city: Two centuries of urban planning and climate science in Manchester (UK) and its region." Cities 29, (2012): 244-251. doi:10.1016/j.cities.2011.10.002.

[106] Malek, Nurhayati Abdul, Manohar Mariapan, and Mustafa Kamal Mohd Shariff. "The Making of a Quality Neighbourhood Park: A Path Model Approach.” Procedia Social and Behavioral Sciences 49, (2012): 202-214. doi:10.1016/j.sbspro.2012.07.019.

[107] Marquet, Oriol, and Carme Miralles-Guasch. "The Walkable city and the importance of the proximity environments for Barcelona's everyday mobility." Cities 42, (2015): 258-266. doi: 10.1016/j.cities.2014.10.012.

[108] Martani, Claudio, David Lee, Prudence Robinson, Rex Britter, and Carlo Ratti. "ENERNET: Studying the dynamic relationship between building occupancy and energy consumption." Energy and Buildings 47, (2012): 584-591. doi:10.1016/j.enbuild.2011.12.037.

[109] Mayer, Audrey L. "Strengths and weaknesses of common sustainability indices for multidimensional systems." Environmental International 34, (2008): 277-291. doi:10.1016/j.envint.2007.09.004.

[110] McCall, Rod, Shaleph OÕNeill, Fiona Carroll, David Benyon and Michael Smyth. "Responsive Environments, Place and Presence." Psych Nology Journal 3, no.1 (2005): 35-73. http://researchrepository.napier.ac.uk/1775/

[111] Meunier, David. "Towards a sustainable development approach in transport assessment." Procedia Social and Behavioral Sciences 48, (2012): 3065-3077. doi:10.1016/j.sbspro.2012.06.1273.

[112] Mihailaa, Marina. "Museum Side of the City - from the Theory to Inquiry." Procedia Social and Behavioral Sciences 149, (2014): 570-574. doi:10.1016/j.sbspro.2014.08.212.

[113] Mohamed, Noralizawati, and Noriah Othman. "Push and Pull Factor: Determining the Visitors Satisfactions at Urban Recreational Area." Procedia Social and Behavioral Sciences 49, (2012): 175-182. doi:10.1016/j.sbspro.2012.07.016.

[114] Morello, Eugenio, and Carlo Ratti. "Sunscapes: Solar envelopes and the analysis of urban DEMs, Computers." Environment and Urban Systems 33, (2009): 26-34. doi:10.1016/j.compenvurbsys.2008.09.005.

[115] Mori, Koichiro, and Aris Christodoulou. "Review of sustainability indices and indicators: Towards a new City Sustainability Index (CSI)." Environmental Impact Assessment Review 32, (2012): 94-106. doi:10.1016/j.eiar.2011.06.001. 
[116] Moriarty, Patrick, and Damon Honnery. "Future cities in a warming world." Futures 66, (2015): 45-53. doi: $10.1016 /$ j.futures.2014.12.009.

[117] Movahed, Sepideh, Sepideh Payami Azad, and Homa Zakeri. "A Safe Pedestrian Walkway; Creation a Safe Public Space Based on Pedestrian Safety." Procedia Social and Behavioral Sciences 35, (2012): 572-585. doi:10.1016/j.sbspro.2012.02.124.

[118] Nasira, Rabiatul Adawiyah, Sabarinah Sh Ahmada, Azni Zain-Ahmed, and Norhati Ibrahima. "Adapting Human Comfort in an Urban Area: The role of tree shades towards urban regeneration." Procedia Social and Behavioral Sciences 170, (2015): 369-380. doi:10.1016/j.sbspro.2015.01.047.

[119] Neirotti, Paolo, Alberto De Marco, Anna Corinna Cagliano, Giulio Mangano, and Francesco Scorrano. "Current trends in Smart City initiatives: Some stylised facts." Cities 38, (2014): 25-36. doi:10.1016/j.cities.2013.12.010.

[120] Nejat, Payam, Abdul Kasir Morsoni, Fatemeh Jomehzadeh, Hamid Behzad, Mohamad Saeed Vesali, and Muhd Zaimi Abd Majid. "Iran's achievements in renewable energy during fourth development program in comparison with global trend." Renewable and Sustainable Energy Reviews 22, (2013): 561-570. doi:10.1016/j.rser.2013.01.042.

[121] Németh, Jeremy, and Joern Langhorst. "Rethinking urban transformation: Temporary uses for vacant land." Cities 40, (2014): 143-150. doi:10.1016/j.cities.2013.04.007.

[122] Ngesana, Mohd Riduan, Hafazah Abdul Karim, and Syed Sobri Zubir. "Image of Urban Public Park during Nighttime in Relation to Place Identity." Procedia Social and Behavioral Sciences 101, (2013): 328-337. doi:10.1016/j.sbspro.2013.07.207.

[123] Ngesana, Mohd Riduan, Hafazah Abdul Karima, Syed Sobri Zubir, and Puziah Ahmad. "Urban Community Perception on Nighttime Leisure Activities in Improving Public Park Design." Procedia Social and Behavioral Sciences 105, (2013): 619-631. doi:10.1016/j.sbspro.2013.11.065.

[124] Nguyena, Binh K., and Hasim Altana. "Comparative review of five sustainable rating systems.” Procedia Engineering 21, (2011): 376-386. doi:10.1016/j.proeng.2011.11.2029.

[125] Nguyena, Binh K., and Hasim Altana. "TPSI - Tall-building Projects Sustainability Indicator.” Procedia Engineering 21, (2011): 387-394. doi:10.1016/j.proeng.2011.11.2030.

[126] Niemelä, Jari. "Ecology of urban green spaces: The way forward in answering major research questions." Landscape and Urban Planning 125, (2014): 298-303. doi:10.1016/j.landurbplan.2013.07.014.

[127] Niroumand, Hamed, M.F.M Zain, and Maslina Jamil. "Building Evaluation based on Sustainable Development using Questionnaire System." Procedia Social and Behavioral Sciences 89, (2013): 454-460. doi:10.1016/j.sbspro.2013.08.877.

[128] Novak, Peter. "Sustainable energy system with zero emissions of GHG for cities and countries." Energy and Buildings 98 (2015): 27-33. doi:10.1016/j.enbuild.2014.10.085.
[129] Nowicka, Katarzyna. "Smart City logistics on cloud computing model." Procedia Social and Behavioral Sciences 151, (2014): 266-281. doi:10.1016/j.sbspro.2014.10.025.

[130] Oktay, Derya. "Design with the climate in housing environments: an analysis in Northern Cyprus." Building and Environment 37, (2002): 1003-1012. doi: 10.1016/S0360-1323(01)00086-5.

[131] Oktay, Derya. "The quest for urban identity in the changing context of the city Northern Cyprus." Cities 19, no.4 (2002): 261-271. doi:10.1016/S0264-2751(02)00023-9.

[132] Oktay, Derya. "Urban design for sustainability: A study on the Turkish city." International Journal of Sustainable Development \& World Ecology 11, no. 1 (2009): 24-35. doi:10.1080/13504500409469808.

[133] Oktay, Derya. Human Sustainable Urbanism: In Pursuit of Ecological and Social-Cultural Sustainability, Procedia Social and Behavioral, 36, (2012): 16-27. doi:10.1016/j.sbspro.2012.03.003.

[134] Papangelis, Giorgos, Maria Tombrou, Aggeliki Dandou, and Themis Kontos. "An urban "green planning" approach utilizing the Weather Research and Forecasting (WRF) modeling system. A case study of Athens, Greece." Landscape and Urban Planning 105, (2012): 174-183. doi:10.1016/j.landurbplan.2011.12.014.

[135] Perovic, Svetlana. "The levels of integrality in architecture and urbanism studies at the University of Montenegro." Procedia Social and Behavioral Sciences 93, (2013): 654-658. doi:10.1016/j.sbspro.2013.09.256

[136] Picazo-Tadeo, Andrés J., Juana Castillo-Giménez, and Mercedes Beltrán-Esteve. "An intertemporal approach to measuring environmental performance with directional distance functions: Greenhouse gas emissions in the European Union." Ecological Economics 100, (2014): 173-182. doi:10.1016/j.ecolecon.2014.02.004.

[137] Pincetl, Stephanie. "Nature, urban development and sustainability - What new elements are needed for a more comprehensive understanding?" Cities 29, (2012): 32-37. doi:10.1016/j.cities.2012.06.009.

[138] Pincetla, Stephanie, Paul Bunje and Tisha Holmes. "An expanded urban metabolism method: Toward a systems approach for assessing urban energy processes and causes." Landscape and Urban Planning 107, (2012): 193-202. doi:10.1016/j.landurbplan.2012.06.006.

[139] Premalatha, M., S.M. Tauseef, T. Abbasin, and S.A. Abbasi. "The promise and the performance of the world's first two zero carbon eco-cities." Renewable and Sustainable Energy Reviews 25, (2013): 660-669.

doi:10.1016/j.rser.2013.05.011.

[140] Rahman, Syumi Rafida Abdul, Hamidah Ahmad, Sapura Mohammad, and Muhamad Solehin Fitry Rosley. "Perception of Green Roof as a Tool for Urban Regeneration in a Commercial Environment: The Secret Garden, Malaysia." Procedia Social and Behavioral Sciences 170, (2015): 128-136. doi:10.1016/j.sbspro.2015.01.022.

[141] Rai, Pallavi Tak. "Townships for sustainable cities." Procedia Social and Behavioral Sciences 37, (2012): 417-426. doi:10.1016/j.sbspro.2012.03.307. 
[142] Ratner, Keith A., and Andrew R. Goetz. "The reshaping of land use and urban form in Denver through transit-oriented development." Cities 30, (2013): 31-46. doi:10.1016/j.cities.2012.08.007.

[143] Ratti, Carlo, Dana Raydan, and Koen Steemers. "Building form and environmental performance: archetypes, analysis and an arid climate." Energy and Buildings 35, (2003): 49-59.

http://senseable.mit.edu/papers/pdf/20030115_Ratti_etal_B uildingForm_EnergyBuildings.pdf.

[144] Ratti, Carlo, Nick Baker, and Koen Steemers. "Energy consumption and urban texture." Energy and Buildings 37, (2005): 762-776. doi:10.1016/j.enbuild.2004.10.010.

[145] Recalde, Marina Yesica, Carina Guzowski, and Mariana Ines Zilio. "Are modern economies following a sustainable energy consumption path?" Energy for Sustainable Development 19, (2014): 151-161. doi: 10.1016/j.esd.2014.01.005.

[146] Ren, Chao, Ka Lun Lau, Kam Po Yiu, and Edward Ng. "The application of urban climatic mapping to the urban planning of high-density cities: The case of Kaohsiung, Taiwan." Cities 31, (2013): 1-16. doi:10.1016/j.cities.2012.12.005.

[147] Rhodes, Joshua D., William H. Gorman, Charles R. Upshaw, and Michael E. Webber. "Using BEopt (EnergyPlus) with energy audits and surveys to predict actual residential energy usage." Energy and Buildings 86, (2015): 808-816. doi: 10.1016/j.enbuild.2014.10.076.

[148] Ribeiro, Renato Guimarães, Francesc Magrinya, and Romulo Dante Orrico Filho. "Study of the changes in urban mobility of the Brazilian middle class, brought about by the population's increased income, and the ensuing impact on urban mass transit." Procedia Social and Behavioral Sciences 160, (2014): 294-303. doi:10.1016/j.sbspro.2014.12.141.

[149] Russo, Francesco, and Antonio Comi. "City characteristics and urban goods movements: A way to environmental transportation system in a sustainable city." Procedia Social and Behavioral Sciences 39, (2012): 61-73. doi:10.1016/j.sbspro.2012.03.091.

[150] Saeidi, Sanaz, and Derya Oktay. "Diversity for Better Quality of Community Life: Evaluations in Famagusta Neighbourhoods." Procedia Social and Behavioral Sciences 35, (2012): 495-504. doi:10.1016/j.sbspro.2012.02.115.

[151] Sahun, Bikash Kumar. "A study on global solar PV energy developments and policies with special focus on the top ten solar PV power producing countries." Renewable and Sustainable Energy Reviews 43, (2015): 621-634. doi:10.1016/j.rser.2014.08.023.

[152] Samet, Robert H. "Complexity science and theory development for the futures field." Futures 44, (2012): 504-513. doi:10.1016/j.futures.2012.02.003.

[153] Setyowati, Erni, Arnis Rochma Harani, and Yasmina Nurul Falah. "The Application of Pedestrian Ways Design Concepts as an Implementation of Sustainable Urban Open Spaces." Procedia Social and Behavioral Sciences 85, (2013): 345-355. doi:10.1016/j.sbspro.2013.08.364.

[154] Shamsuzzoha Ahm, Andy Grant, and Joe Clarke. "Implementation of renewable energy in Scottish rural area:
A social study." Cities 16, (2012): 185-191. doi:10.1016/j.rser.2011.07.146.

[155] Sharifi, Ayyoob, and Akito Murayama. "A critical review of seven selected neighborhood sustainability assessment tools.' Environmental Impact Assessment Review 38, (2013): 73-87. doi:10.1016/j.eiar.2012.06.006.

[156] Sharifi, Ayyoob, and Akito Murayama. "Neighborhood sustainability assessment in action: Cross-evaluation of three assessment systems and their cases from the US, the UK, and Japan." Building and Environment 72, (2014): 243-258. doi:10.1016/j.buildenv.2013.11.006.

[157] Sharifi, Ayyoob, and Akito Murayama. "Viability of using global standards for neighbourhood sustainability assessment: insights from a comparative case study." Environmental Planning and Management 58 no. 1, (2014): 1-23. doi: 10.1016/j.buildenv.2013.11.006.

[158] Sharifi, Ayyoob, Yoshihiro Chiba, Kohei Okamoto, Satoshi Yokoyama, and Akito Murayama. "Can master planning control and regulate urban growth in Vientiane, Laos?" Landscape and Urban Planning 131 (2014): 1-13. doi:10.1016/j.landurbplan.2014.07.014.

[159] Shearmur, Richard. "Are cities the font of innovation? A critical review of the literature on cities and innovation." Cities 29, (2012): 9-18. doi:10.1016/j.cities.2012.06.008.

[160] Shen, Liyin, Yi Peng, Xiaoling Zhang, and Yuzhe Wu. "An alternative model for evaluating sustainable urbanization." Cities 29, (2012): 32-39. doi:10.1016/j.cities.2011.06.008.

[161] Shia, Yaqi, Xiang Suna, Xiaodong Zhua, Yangfan Li, and Liyong Mei. "Characterizing growth types and analyzing growth density distribution in response to urban growth patterns in peri-urban areas of Lianyungang City." Landscape and Urban Planning 105, (2012): 425-433. doi:10.1016/j.landurbplan.2012.01.017.

[162] Shuib, Kamarul Bahrain, Habsah Hashim, and Nurul Akmaniza Mohd Nasir. "Community Participation Strategies in Planning for Urban Parks." Procedia Social and Behavioral Sciences 168, (2015): 311-320. doi:10.1016/j.sbspro.2014.10.236.

[163] Sıvalıŏlu, Pınar, and Lale Berkız. "Perceptual Evaluation of the National Park Users." Procedia Social and Behavioral Sciences 50, (2012): 928-940. doi:10.1016/j.sbspro.2012.08.094.

[164] Singh, R. K., H.R. Murty, S. K. Gupta, and A. K. Dikshit. "An overview of sustainability assessment methodologies." Ecological Indicators 9, (2009): 198-212. doi:10.1016/j.ecolind.2008.05.011.

[165] Snieška Vytautas, and Ineta Zykiene. "The role of infrastructure in the future city: theoretical perspective." Procedia Social and Behavioral Sciences, 156, (2014): 247-251. doi:10.1016/j.sbspro.2014.11.183.

[166] Sozen Adnan, and Erol Arcaklioglu. "Prediction of net energy consumption based on economic indicators (GNP and GDP) in Turkey." Energy Policy 35, (2007): 4981-4992. doi:10.1016/j.enpol.2007.04.029.

[167] Stana, Angelica. "The City's Creative Writing: From Morphology to Virtual Landscape." Procedia Social and Behavioral Sciences 149, (2014): 901-905. doi:10.1016/j.sbspro.2014.08.279. 
[168] Stenberg, Jenny, and Lasse Fryk. "Urban empowerment through community outreach in teaching and design." Procedia Social and Behavioral Sciences 46, (2012): 3284-3289. doi:10.1016/j.sbspro.2012.06.052.

[169] Stumpp, Eva-Maria. "New in town? On resilience and "Resilient Cities." Cities 32, (2013): 164-166. doi:10.1016/j.cities.2013.01.003.

[170] Szitar, Mirela-Adriana. "Learning about sustainable community development." Procedia Social and Behavioral Sciences 116, (2014): 3462-3466. doi:10.1016/j.sbspro.2014.01.784.

[171] Taleai, Mohammad, Richard Sliuzas, and Johannes Flacke. "An integrated framework to evaluate the equity of urban public facilities using spatial multi-criteria analysis." Cities 40, (2014): 56-69. doi:10.1016/j.cities.2014.04.006.

[172] Tan, Puay Yok, James Wang, and Angelia Sia. "Perspectives on five decades of the urban greening of Singapore." Cities 32, (2013): 24-32. doi:10.1016/j.cities.2013.02.001.

[173] Taniguchi, Eiichi. "Concepts of city logistics for sustainable and liveable cities." Procedia Social and Behavioral Sciences, 151, (2014): 310-317. doi:10.1016/j.sbspro.2014.10.029.

[174] Thani, Sharifah Khalizah Syed Othman, Nik Hanita Nik Mohamad, and Sabrina Idilfitri. "Modification of Urban Temperature in Hot-Humid Climate through Landscape Design Approach: A review." Procedia Social and Behavioral Sciences 68, (2012): 439-450. doi:10.1016/j.sbspro.2012.12.240.

[175] Torreggiani, Daniele, Enrica Dall'Ara and Patrizia Tassinari. "The urban nature of agriculture: Bidirectional trends between city and countryside." Cities 29, (2012): 412-416. doi:10.1016/j.cities.2011.12.006.

[176] Ucakturk, Ahmet, and Harun Demirkaya. "Power Perception of Developing Countries in Their Sustainable Growth and Innovation Strategies." Procedia Social and Behavioral Sciences 99, (2013): 112-121. doi:10.1016/j.sbspro.2013.10.477.

[177] Ujang, Norsidah, and Khalilah Zakariya. "The Notion of Place, Place Meaning and Identity in Urban Regeneration." Procedia Social and Behavioral Sciences 170, (2015): 709-717. doi:10.1016/j.sbspro.2015.01.073.

[178] Ulhoi, John P., and Henning Madsen. "New patterns in corporate sustainable development?" Procedia Social and Behavioral Sciences 99, (2013): 46-56. doi:10.1016/j.sbspro.2013.10.470.

[179] Vasilea, Emilia, Mariana Man. "Current dimension of environmental management accounting." Procedia Social and Behavioral Sciences 62, (2012): 566-570. doi:10.1016/j.sbspro.2012.09.094.

[180] Verlinde, Sara, Cathy Macharis, and Frank Witlox. "How to consolidate urban flows of goods without setting up an urban consolidation centre?" Procedia Social and Behavioral Sciences 39, (2012): 687-701. doi:10.1016/j.sbspro.2012.03.140.

[181] Viegas, Cláudia V., Dejanira Luderitz Saldanha, Alan Bond, José Luis Duarte Ribeiro, and Paulo M. Selig. "Urban land planning: The role of a Master Plan in influencing local temperatures." Cities 35, (2013): 1-13. doi:10.1016/j.cities.2013.05.006.

[182] Vojnovic, Igor. "Urban sustainability: Research, politics, policy and practice." Cities 41, (2014): 30-44. doi:10.1016/j.cities.2014.06.002.

[183] Wang, Hao, Qiping Shen, Bo-sin Tang, Chen Lu, Yi Peng, and LiYaning Tang. "A framework of decision-making factors and supporting information for facilitating sustainable site planning in urban renewal projects." Cities 40, (2014): 44-55. doi:10.1016/j.cities.2014.04.005.

[184] Wang, Xiaoxia, Zhong Liu, and Yue Shang. "Sustainable Analysis Architecture and Optimization of Urban Freight under Congestion." Procedia Social and Behavioral Sciences 138, (2014): 418-426. doi:10.1016/j.sbspro.2014.07.220.

[185] Wanga, Haijun Sanwei He, Xingjian Liu, Lan Dai, Peng Pana, Song Hong, and Wenting Zhang. "Simulating urban expansion using a cloud-based cellular automata model: A case study of Jiangxia, Wuhan, China." Landscape and Urban Planning 110, (2013): 99-112. doi:10.1016/j.landurbplan.2012.10.016.

[186] Waslekar, Saahil Sundeep. "World environmental Kuznets curve and the global future." Procedia Social and Behavioral Sciences 133, (2014): 310-319. doi:10.1016/j.sbspro.2014.04.197.

[187] Winthrop, Robert H. "The strange case of cultural services: Limits of the ecosystem services paradigm." Ecological Economics 108, (2014): 208-214. doi: 10.1016/j.ecolecon.2014.10.005.

[188] Wolch, Jennifer R., Jason Byrne, and Joshua P. Newell. "Urban green space, public health, and environmental justice: The challenge of making cities "just green enough." Landscape and Urban Planning 125, (2014): 234-244. doi:10.1016/j.landurbplan.2014.01.017.

[189] Wonorahardjo, Surjamanto. "New Concepts in Districts Planning, Based on Heat Island Investigation." Procedia Social and Behavioral Sciences 36, (2012): 235-242. doi:10.1016/j.sbspro.2012.03.026.

[190] Wu, Jianguo. "Urban ecology and sustainability: The state-of-the-science and future directions." Landscape and Urban Planning 125, (2014): 209-221. doi:10.1016/j.landurbplan.2014.01.018.

[191] Xing, Yangang, R. Malcolm W. Horner, Mohamed A. El-Haram, and Jan Bebbington. "A framework model for assessing sustainability impacts of urban development." Accounting Forum 33, (2009): 209-224. doi:10.1016/j.accfor.2008.09.003.

[192] Xing, Yanying, Hongyan Liang, and Dongbin $\mathrm{Xu}$. "Sustainable development evaluation of urban traffic system." Procedia Social and Behavioral Sciences 96, (2013): 496-504. doi:10.1016/j.sbspro.2013.08.058.

[193] Yadava, Priyanka, Kathy Duckworthb, and Parwinder S. Grewala. "Habitat structure influences below ground biocontrol services: A comparison between urban gardens and vacant lots." Landscape and Urban Planning 104, (2012): 238-244. doi:10.1016/j.landurbplan.2011.10.018.

[194] Yaldiz, Esra, Dicle Aydın, and Süheyla Buyuksahin Siramkaya. "Loss of City Identities in The Process of 
Change: The City of Konya-Turkey." Procedia Social and Behavioral Sciences 140, (2014): 221-233. doi:10.1016/j.sbspro.2014.04.413.

[195] Yilmaz, Zerrin. "Ak1llı Binalar ve Yenilenebilir Enerji." Tesisat Mühendisliği Dergisi 91, (2006): 7-15. http://www.mmo.org.tr/resimler/dosya_ekler/7af0926b294e 47e_ek.pdf?dergi.

[196] Yirmibesoglu, Funda, and Nilgun Ergun. "Property and Personal Crime in Istanbul." European Planning Studies 15, no. 3 (2007): 339-355. doi: 10.1080/09654310601017067.

[197] Yuan, Xueliang, Xujiang Wang, and Jian Zuo. "Renewable energy in buildings in China - A review." Renewable and Sustainable Energy Reviews 24, (2013): 1-8. doi:10.1016/j.rser.2013.03.022.
[198] Zahari, F., and T. Ramayah. "Behind the green doors: What management practices lead to sustainable innovation?" Procedia Social and Behavioral Sciences 65, (2012): 247-252. doi:10.1016/j.sbspro.2012.11.118.

[199] Zeng, Chen, Mengdi Zhang, Jiaxing Cui, and Sanwei He. "Monitoring and modeling urban expansion: A spatially explicit and multi-scale perspective." Cities 43, (2015): 92-103. doi: 10.1016/j.cities.2014.11.009.

[200] Zundera, Thomas H., Paulus T. Aditjandraa, and Bruce Carnabya. "Developing a Local Research Strategy for City Logistics on an Academic Campus." Procedia Social and Behavioral Sciences 125, (2014): 226-238. doi:10.1016/j.sbspro.2014.01.1469. 